\title{
Traduire
}

Une autre perspective sur r tr traduction

Revue française de la traduction

$221 \mid 2009$

Voies de l'interprétation

\section{Recommandation d'une lectrice : Le Sot de l'ange}

\section{Claudie Pons}

\section{OpenEdition}

Journals

Édition électronique

URL : http://journals.openedition.org/traduire/367

DOI : 10.4000/traduire.367

ISSN : 2272-9992

Éditeur

Société française des traducteurs

Édition imprimée

Date de publication : 15 décembre 2009

Pagination : 119

ISSN : 0395-773X

\section{Référence électronique}

Claudie Pons, «Recommandation d'une lectrice : Le Sot de l'ange », Traduire [En ligne], 221 | 2009, mis en ligne le 12 novembre 2013, consulté le 27 novembre 2020. URL : http://journals.openedition.org/ traduire/367 ; DOI : https://doi.org/10.4000/traduire.367 


\title{
Recommandation d'une lectrice : Le Sot de l'ange
}

\author{
Claudie Pons
}

\section{RÉFÉRENCE}

Le Sot de l'ange, Christopher Moore, Éditions Calmann-Lévy, 2006, traduit de l'américain par Luc Baranger, 251 p., 16,50€

1 Au hasard de mes lectures, j'ai lu récemment Le Sot de l'ange de Christopher Moore. Pourquoi ai-je pris cet ouvrage ? Le jeu de mots du titre m'a intriguée. Et quand j'ai lu le titre original The Stupidest Angel, ça m'a faire rire. Alors j'ai lu.

2 Je ne connais pas Christopher Moore. Il semblerait surtout qu'il ne se prenne pas au sérieux (intéressant, déjà !!) : une histoire délirante, du n'importe quoi, déjanté en diable, ça part en vrille, on aime ou pas les zombies ; mais le rembobinage de la fin est sympa.

3 En revanche, côté traduction, que du bonheur, malgré quelques détracteurs trouvés sur le net. Pour ma part, j'ai trouvé : style enlevé, vocabulaire actuel, un bon rythme, du $2^{\mathrm{e}}$ degré souvent, des jeux de mots absolument bien rendus en français. Bref (à condition qu'on rentre dans l'histoire, voir ci-dessus), on n'a pas l'impression de lire une traduction, mais de lire un bouquin. Et ça, c'est une BONNE traduction.

4 Étonnant : j'ai rendu le livre à la bibliothèque de mon village et avais oublié de noter le nom du traducteur. Je viens de chercher sur le site de Calmann-Lévy : il n'est même pas mentionné !! Il s'agit de Luc Baranger. Bravo, collègue ! 